\title{
Cuento
}

\section{Manual para \\ Olvidarlo Todo}

Manual to Forget Everything

Germán Valenzuela Rodríguez ${ }^{1}$

"I don't owe you anything, no But you owe me something,

Repay me now"

Steven Patrick Morrissey

$\mathfrak{G}$ una tarde de miércoles, creo. Estamos en un auditorio improvisado en el espacio que ocupa la salita de espera del piso tres. Somos como treinta, quizás un poco más. Es improbable que seamos menos.

Junto a mí hay tres o cuatro personas que como yo, están en silla de ruedas. Debo ser el menor de todos y lo digo especulando sobre la forma que mi rostro debería tener. Pocas arrugas, ninguna cana, eso espero.

Mientras escucho el sonido de una voz desconocida, descubro que puedo mover las piernas y los brazos. Que mis sensaciones están conservadas también.

¿Quién se habrá atrevido a colocarme en esta silla? ¿Cómo habré terminado aquí? Esos cuerpos decrépitos se han confabulado para hacerme pasar un mal rato, digo, pero casi instantáneamente un miedo intenso me

1 Médico internista y cardiólogo.

Cuento ganador del Concurso de Cuento, Colegio Médico del PerúConsejo Regional III, Lima, octubre del 2019. gobierna. Ellos tienen la mirada perdida, visten ropas desgastadas y huelen mal.

Mi acompañante es una mujer bajita, de unos cincuenta años, sin belleza y sin glamour. Ha descubierto que puede vigilarme desde una distancia prudencial dando la impresión de que no estuviera. No sé su nombre. Tampoco entiendo qué hago en esa extraña reunión, por lo que me entretengo con una risa, de esas que vienen acompañadas de otros sonidos casi sin pensar.

Sin pensar te he hablado en una noche de setiembre. Tú no me crees pero yo soy un cobarde. No sé cómo se me ocurrió invitarte a salir. Debe ser porque ya me cansé de recibir tus reprimendas en las clases de Anatomía sin explicarte mis motivos: me río porque creo que la vida es divertida. Me río de los demás porque no saben dónde se ubica el Triángulo de Scarpa o el Homúnculo de Penfield. Lo hago simplemente porque me provoca hacerlo. Algunas veces me he reido de ti. No ahora, por supuesto. Tú me dices que soy interesante, que te parece raro encontrar a un hombre a quien le guste "The Smiths".

"The Smiths" sefundó en el año 1982 ysus miembros 
procedian de familias inmigrantes irlandesas. En sus cinco años de unión lanzaron 4 discos de estudio y muchos compilatorios. Morrissey cuyo verdadero nombre es Steven Patrick Morrissey admiraba a Oscar Wilde y se caracterizó por escribir e interpretar canciones cuyas letras eran verdaderos poemas. Sin embargo, las letras de las canciones no son únicamente responsables de esa magia-te digo. Mucho se le debe a John Martin Maher, que es el nombre original de Johnny Marr, pues sus acordes fueron la compañia perfecta para esas letras e hicieron que las adoptáramos, confundiéndolas con algunas experiencias de nuestra vida. Como nos sucede ahora. Tú eres como esas letras y yo soy un grupo de acordes complejos. Juntos somos más que dos.

Dos unidades serán necesarias si existiera un efecto incompleto. Esto quiere decir que si se mantuviera la agitación o la incapacidad de incorporarse a las labores de la cotidianeidad, podrían eventualmente ser necesarios hasta dos parches de $5 \mathrm{~cm} 2$. Aún no han llegado los parches de 10 pero dos de 5 son equivalentes y con su uso es posible evaluar de manera más cercana el efecto terapéutico, ¿entendido? -dice el hombre frente a nosotros, vestido de mandil blanco y que contesta a las preguntas de manera hostil, como si lo hubieran obligado a hablarnos.

A pesar de ello, las mujeres jóvenes que acompañan a los ancianos lo escuchan atentamente anotando algunos datos en libretas, en pedazos de papel o en las palmas de sus manos.

Manos gruesitas tienes, pienso. Manos con palmas endurecidas por la vida, por las malas experiencias, porque son ellas las que nos endurecen. Las buenas nos dejan integros, como si fuésemos sus testigos privilegiados. Tú me has dicho que viniste a Lima a los quince. Que postulaste a la facultad de Medicina y la agarraste a la tercera. Menudo sacrificio el tuyo, ¿eh?. No puedo imaginarte viviendo en un cuarto de adobe con puertas de madera. Cargando baldes de agua los dias impares porque en esa vieja casa, los inquilinos más antiguos habian decidido que era la mejor manera de reducir los gastos comunes. Decorando las paredes con figuras religiosas, posters de Morrissey y estrellas - en los pequeños orificios por donde la luz se camuflaba-porque las estrellas y los ángeles, sabemos bien, se encuentran sólo lejos de la tierra.

Dicen que los ángeles son blancos pero yo nunca he creído en ellos.

Sólo sé que el blanco es el color más difícil de cuidar. Las pieles blancas son débiles y cambian de color con las temperaturas altas o con el frío. Las ropas blancas terminan casi siempre siendo negras o grises.

Te recuerdo blanca, llena de vida, el cabello ondulado, castaño. Recuerdo tus formas exageradas. Las tetas grandes, decoradas por dos pezones rosados. Esas nalgas redondas sobre las cuales me dormía después de una guardia en nuestro internado. Hospital Guillermo Almenara, Avenida Grau 800 ¿te acuerdas?.

El abdomen blando, plano, decorado por una cicatriz de una operación antigua. Tu rostro frente al mio. El cuerpo protegido por unas ropas ligeras y un mandil sucio que contrastaba con la candidez que reflejabas, con el amor que equivocadamente pensé que solo era mío, que solo sería para mí.

Mi enfermedad comenzó a los veintiséis. Un monstruo interior comenzó a devorarse mis recuerdos. Al principio olvidé números, direcciones, síntomas, resultados, nombres. En pocos meses olvidé a "The Smiths" a pesar de que volví a escuchar sus canciones repetidamente sin reconocerlas. 
Con la esperanza de minimizar los síntomas me transformé en un ser ordenado que cubría sus caminos con papeles, a modo de señales o alarmas, para entender qué estaba haciendo o qué había hecho, aún cuando el método habitualmente fallaba; eso me dijeron los cinco, seis o más neurólogos que analizaron mi caso (sus nombres los he olvidado, sus rostros también). Ellos me hicieron algunas pruebas sanguíneas, punciones lumbares (siempre son dolorosas), repetidas tomografías (la mayoría de contrastes inflaman las venas) y un número mayor de resonancias cerebrales (el sonido que emiten es inversamente proporcional a la calidad de sus imágenes).

Los meses más fáciles estuviste conmigo. A tu lado aprendí a no extrañar los recuerdos pues mi cuerpo se entretenía con el tuyo, algunas veces en el hospital (lo hubiera olvidado si no estuviera aquí mismo), en un hotelito sin nombre escondido en el Jirón Cangallo frente a la Emergencia (de "can" que es lata en inglés, y "gallo" que es el ave dibujada en mis zapatillas), otras en sitios que no vienen a mi mente, por no haber sido planeadas quizás.

Sin embargo, algunos recuerdos hacen daño. Tú me hiciste daño al hacerme la promesa de tu compañía eterna (sabíamos que nada en esta vida dura para siempre).
Por eso estoy aquí. Solo. Amarrado a esta estructura de metal. Recordando tu cruel manera de decirme adiós: me voy porque no quiero sufrir. Intentaré olvidarte aunque es posible que tú ya me hayas olvidado, me dijiste, abandonándome a mi suerte, con una dirección extranjera en el bolsillo y una extensa carta llena de frases hirientes que mis familiares decidieron no leerme jamás.

Decido sumergirme en el mar de mi pasado. Busco el color de algunos pedazos de ti. No lo consigo. Eres como una sombra que a veces pierde su forma irregular hasta que desaparece. Observo mis manos y los rostros de los ancianos vigilando los pisos o los techos de la salita, buscando quizás cielos o infiernos en esta tierra. Decido hacer lo mismo dirigiendo la mirada hacia un punto distante mientras muevo los brazos y piernas desordenadamente. Un coro de llantos y gemidos cuyo significado no puedo entender me detiene. Observo sus rostros vacíos una vez más.

Elijo apagarme. Con los ojos abiertos, me duermo.

\section{CORRESPONDENCIA:}

german.v.valenzuela@gmail.com

FECHA DE RECEPCIÓN: 21-10-2019.

FeCHA DE ACEPTACIÓN: 20-12-2019. 